\title{
Adopting seasonal regimen (Ritucharya) to modulate the seasonal variation in gut microbiome
}

\author{
Deepthi. R*, Vandana Rani M, Delvin T. Robin and Anusree Dileep
}

\begin{abstract}
The science of Ayurveda with its strong and unique fundamentals holds its domain forever amidst all scientific and medical advancements. The concept of Shadkriyakala (the different phases of disease formation) holds relevance in preventive medicine and public health management as it provides ample chance to halt the disease process at each stage by timely intervention. In this review, we would like to bring to the limelight the relevance of Ritucharya (seasonal regimen) in primary prevention by modulating the gut microbiota. The modern gut microbiome researches now help us to better explore the Ayurveda theories of Agni (digestive fire) and Ama (metabolic toxins) preached centuries back. Ayurveda firmly proclaims that no disease ever arises without the derangement of Agni (digestive fire). The whole preventive and treatment methodology in Ayurveda focuses upon the modulation and management of "Agni" (digestive fire). When the functioning of Agni is deranged, Ama (metabolic toxin) is produced and it vitiates the doshas which spread throughout the body and manifest as varied diseases. A biomedical perspective of our reviews suggests that dysbiosis of microbial flora can cause a leaky gut by which the toxins of deranged digestive metabolism enter the bloodstream. Consequently, an inflammatory response occurs within the body which expresses out as diseases opportunistically. We meticulously reviewed the influence of extrinsic factors namely diet and climate on human gut microbiota, and our analysis emphasises the application prospects of Ritucharya (seasonal regimen), in regulating the dynamic host-microbe interaction.
\end{abstract}

Keywords: Gut microbiota, Gut microbiome, Gut health, Ritucharya, Seasonal gut biota, Seasonal diet and gut biota, Agni

\section{Introduction}

Six ritus (seasons) have been detailed by the Ayurveda Samhitas (ancient Ayurvedic texts) three each under the gross classifications as Aadana kala (Northern Solstice) and Visarga kala (Southern Solstice), and specific dietary and lifestyle regimen has been advocated for each. Presently, the India Meteorological Department identifies four seasons markedly distinguishable all across the country, with a basic wet and dry tropical climate.

The human gut microbiome is as vital as any other body organ. The gut microbiota participates in host

\footnotetext{
* Correspondence: deeps.srp@gmail.com

Department of Swastha Vrittam (Social and Preventive Medicine), Amrita School of Ayurveda, Amrita Vishwa Vidyapeetham, Amritapuri, India
}

metabolism, immunity, pathogenesis, gene expression, food and drug efficacy. The basic advocacy of Ayurveda on the prime necessity of gut health is reaffirmed by the modern gut microbiome researches. Hence, an in-depth knowledge of the association of the human gut microbiome with the varying seasons and consequently the relevance of seasonal regimens prescribed in Ayurveda known as Ritucharya is essential. The human gut microbiota colonisation gets initiated at birth and gets established by 1 year of age primarily based on the delivery mode and the infant feeding method but continues to be influenced by diet, living environment, lifestyle, age, antibiotics and time. However, diet is recognised to be the most significant determinant of human gut microbiome

(c) The Author(s). 2021 Open Access This article is licensed under a Creative Commons Attribution 4.0 International License, which permits use, sharing, adaptation, distribution and reproduction in any medium or format, as long as you give appropriate credit to the original author(s) and the source, provide a link to the Creative Commons licence, and indicate if changes were made. The images or other third party material in this article are included in the article's Creative Commons licence, unless indicated otherwise in a credit line to the material. If material is not included in the article's Creative Commons licence and your intended use is not permitted by statutory regulation or exceeds the permitted use, you will need to obtain permission directly from the copyright holder. To view a copy of this licence, visit http://creativecommons.org/licenses/by/4.0/. 
composition. The nutritional value of food ingested, thermoregulation, the immune system and physiological functions can be regulated by the gut microbial population of the individual. A healthy microbiota with beneficial strains dominating harmful ones aids host metabolic homeostasis whereas a dysbiosis trigger up its diseaseinducing potential. The human gut is predominantly occupied by Actinobacteria, Bacteroidetes, Firmicutes, Proteobacteria and Verrucomicrobia, and also with sparse populations of Fusobacteria, Cyanobacteria, Spirochaetes and Saccharibacteria [1].

\section{Methods}

We searched literature databases PubMed, Scopus, MEDLINE and AYUSH Portal. A review of peerreviewed original research articles and reviews published from January 1996 to March 2020 was done. Articles were selected using the search terms: "gut microbiota", "human gut biome", "seasonal microbiota", "host-microbiome interaction", "diet-microbiota" and "microbiota modulators".

"Human gut biome" in conjunction with "seasons" yielded 40 results. After screening all these articles, 12 articles perceived to be of relevance were chosen for further study. Zero results were found for search using gut microbiome combined with Ritucharya. Classical treatises and authentic websites were also referred.

\section{Seasons and gut microbiome}

Tremendous data has revealed a strong association of the gut microbiota with environmental factors like changing seasons and temperature as well as with diet [2, 3]. The studies of Davenport (2014) and Smits (2017) on indigenous populations like Hutterites and Hadza huntergatherers establish that the human gut microbiome varies seasonally, in the abundance of particular taxa as well as in overall gut microbiome diversity $[4,5]$. The causal factor for this shift is hypothesised to be the seasonal dietary differences along with less recognised influential factors like humidity, temperature and the duration of time spent outdoors which differed by seasons in these populations.

In mammals, on exposure to cold, a characteristic shift in the gut microbial community and consequent impacts on total energy homeostasis was observed by which Chevalier et al reports that digestive services by the gut microbiota are also temperature-dependent [6].

Understanding that the human gut microbiota is inevitably influenced by cycling seasons as well as by diet, brings Ritucharya to the limelight as the most effective method to manipulate and regulate the intrinsic hostmicrobiota relationship. Providing the right gut environment through the right seasonal diet can cultivate the right microbiome that could render positive metabolic effects and can be conducive to prevent seasonal and opportunistic infections. Dysbiosis of the gut microbial composition has been associated to a wide range of pathologies like asthma, gastritis, obesity, colitis and eczema.

Diet could modulate the gut microbiota composition in two ways: (1) by including viable microorganisms that resist digestion, colonise the gut and beneficially modulate the microbial composition (probiotics) and (2) by providing non-digestible substrates that feed the intestinal flora and particularly nourish the growth and activity of beneficial microbes (prebiotics).

Probiotics can manipulate the multiplicity, structure and function of the gut microbiota. Probiotics could induce mucin production and maintain tight junctions in the gut epithelium thus fortifying the intestinal barrier against enteric pathogens. They also modulate the intestinal immunity and microbial flora population by inducing IgA and $\beta$-defensin production by the host.

Amino acids, vitamins and dietary fibres absorbed by the host are metabolised by the intestinal microbes into other metabolites like serotonin and gammaaminobutyric acid (GABA) which by itself is physiologically and pathologically significant and is also crucial in altering the microbial composition. Fermentation of prebiotic carbohydrates in the intestinal lumen encourages an explosion of beneficial microbes mainly Bifidobacterium and Lactobacillus species and produces acetate, butyrate and propionates (SCFAs) that forms the primary energy basis for the intestinal epithelial cells.

\section{Analysing gut microbial shift in ritus (seasons) and potential strategy of Ritucharya (seasonal regimen)}

The microbiome profile collected using 16s ribosomal RNA sequencing done in the Hadza (hunter-gatherers) and Hutterites (agriculturists) populations revealed the variations in the microbial population in sync with changing seasons $[4,5]$.

In Hadza during the wet season, when they consumed more foraged foods, berries and honey, Bacteroidetes mainly the Prevotellaceae spp. reduced considerably. During the dry season, the Prevotella species were found to be abundant along with a dramatic drop down in wet microbiota.

In Hutterites too, the phylum Bacteroidetes was observed to be more abundant during the summer than in winter.

\section{Hemanta and Sisira Rithucharya (early and late winter regimen)}

The Hemantha and Sisira Ritu prevails from midNovember to mid-March (Fig. 1). The seasons are characterised by snowfall and mist in many places. As the 


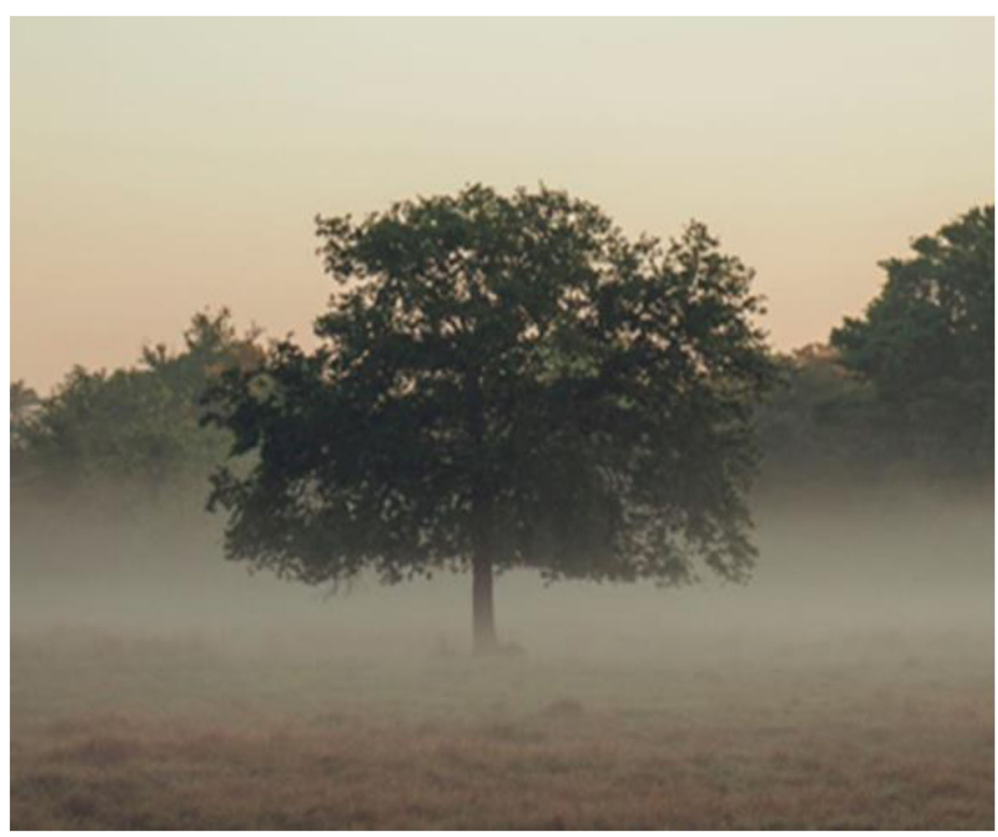

Fig. 1 Hemanta Ritu (misty morning)

temperature goes down, the digestive fire gets flared up and the appetite and craving for food increases. The people will have strong digestive power, and hence, food taken should be quantitatively and qualitatively rich which otherwise could devour the bodily dhatus (tissues) itself (autolysis).

Hence, in Hemanta and Sisira (early and late winter), it is advised to take snigdha ahara (fatty foods), vasa (muscle fat), taila (oil) and sura (fermented products) from jaggery and foods prepared out of navamannam (freshly harvested grains), Ikshu (sugarcane), Masha (black gram) and Godhuma (wheat) [7]. This constitutes a high-fat, high-sugar diet. Takra (buttermilk), ghrita (cow's ghee) and other ksheera vikruti (dairy products) are also recommended that could be substantiated by the fact that the intake of dairy products fermented with beneficial bacteria (Lactobacillus) could enhance the butyrate-producing microbiota and may also inhibit pathogen colonisation in the gut, thus preventing various infections [8].

On the other hand, the phylum Firmicutes is typical gram-positive bacteria, the overgrowth of which is directly involved with obesity. During these seasons, it is advised to practise vyayama (exercise), udvartana (powder massage), abhyanga (oil massage), swedana (sudation) and atapasevana (basking in Sun), which can rightly be complementary to the gut flora changes and health consequences as it is proven that despite a highfat diet, regular exercise could prevent obesity by altering the population ratio of major bacterial phyla, protecting the intestinal morphology and integrity, and thereby reducing inflammatory infiltrate $[9,10]$.

During cold seasons (hemanta, sisira), the relative abundance of Akkermansia (phylum Verrucomicrobia) declines and that of Firmicutes tend to increase. Akkermansia is negatively associated with energy extraction from diet in cold conditions. Hence, the absence of Akkermansia enables increased caloric uptake whereas the Firmicutes which is a cold microbiota increases the caloric uptake as well as enhances the intestinal absorptive capacity. Hence, diet that favours the declining trend of Akkermansia and blooming up of Firmicutes has to be resorted. A high-fat diet reduces Akkermansia abundance in the gut as a co-evolutionary mechanism, facilitating the uptake of increasingly obtainable food energy. At the same time, a high fatty and sugary diet enhances Firmicutes, Mollicutes and Eubacterium which produce short-chain fatty acids (SCFAs) [11, 12]. It has been reported that SCFAs can enhance IL-10 (interleukin 10) expression, hinder the production of pro-inflammatory cytokines, activate Tregs (regulatory $\mathrm{T}$ cells) and relieve colonic inflammation. SCFAs, mainly butyrates, have a crucial role in intestinal epithelial cell proliferation, differentiation, metabolism and reinforcing the colon defense barrier. Butyrates and propionates also have a crucial role in suppressing inflammatory reactions by regulating Foxp3+ Treg cells.

Since most butyric acid-producing bacteria belong to the Firmicutes, its decrease can weaken these protective factors and make the body prone to inflammations as 
substantiated by the findings of low levels in SCFAs in people with ulcerative colitis and other intestinal inflammatory conditions.

The population of Actinobacteria is also observed to rise during winter with a proven positive association of its abundance with the amount of fat consumed [13]. These cold microbiota help the host to cope with cold seasons of high-energy demand by mediating the remodelling of the fat and intestinal tissues [14, 15].

Hence, in Hemanta and Sisira (early and late winter), it is rightly advised to take the above-mentioned foods (Figs. 2 and 3).

\section{Greeshma Rithucharya (summer regimen)}

The Greeshma Ritu commences by mid of May and extends to mid of July (Fig. 4). The season is characterised by intense heat of the Sun which drains human energy. The Agni bala (digestive power) of man will also be considerably less. Excessive rookshatha (dryness) and ushna guna (heat) prevail outside and inside the human body. Hence, in Greeshma (summer), it is advised to take food predominant of swadu rasa (sweet) and sheeta guna (cold in potency), which include rice, milk, ghee, grapes, coconut water and sugar [16]. Coconut water is low in calories and fat and is rich in natural sugars, proteins and antioxidants. Saktu (roasted barley flour) products, Rasala (well-churned curd added with sugar and pepper) and Shadava (juice prepared with various fruits) like sweetened orange juices, bananas and pomegranates are well indicated. (Figs. 5 and 6). Resorting to these food items could favour the genus Bacteroides (Bacteriodetes phylum), the polysaccharide utilisers of the colon and Saccharolytic species belonging to the genus Bifidobacterium and Ruminococcus that grow on carbohydrate substrates. A high-fat, high-sugar diet has to be avoided during Greeshma Ritu (summer season) as it has been associated with a decrease in Bacteroidetes.

Whole grains are potent sources of resistant starch, oligosaccharides and non-digestable carbohydrates that favour Prevotella, Xylanibacter and Treponema which can ferment carboxymethylcellulose, xylene and xylose to produce high levels of SCFAs [17].

The Bacteroidetes clade with genomes containing large numbers of carbohydrate-active enzymes (CAZymes) and in turn specialists in degrading plant cell walls and complex carbohydrates [18] was observed to rise in the Hutterites population during the summer. This was in agreement with the observation that during summer, the Hutterites resorted much to fruits and vegetables than in winter.

There is a natural decline in the Actinobacteria population during summer which is scientifically attributed to

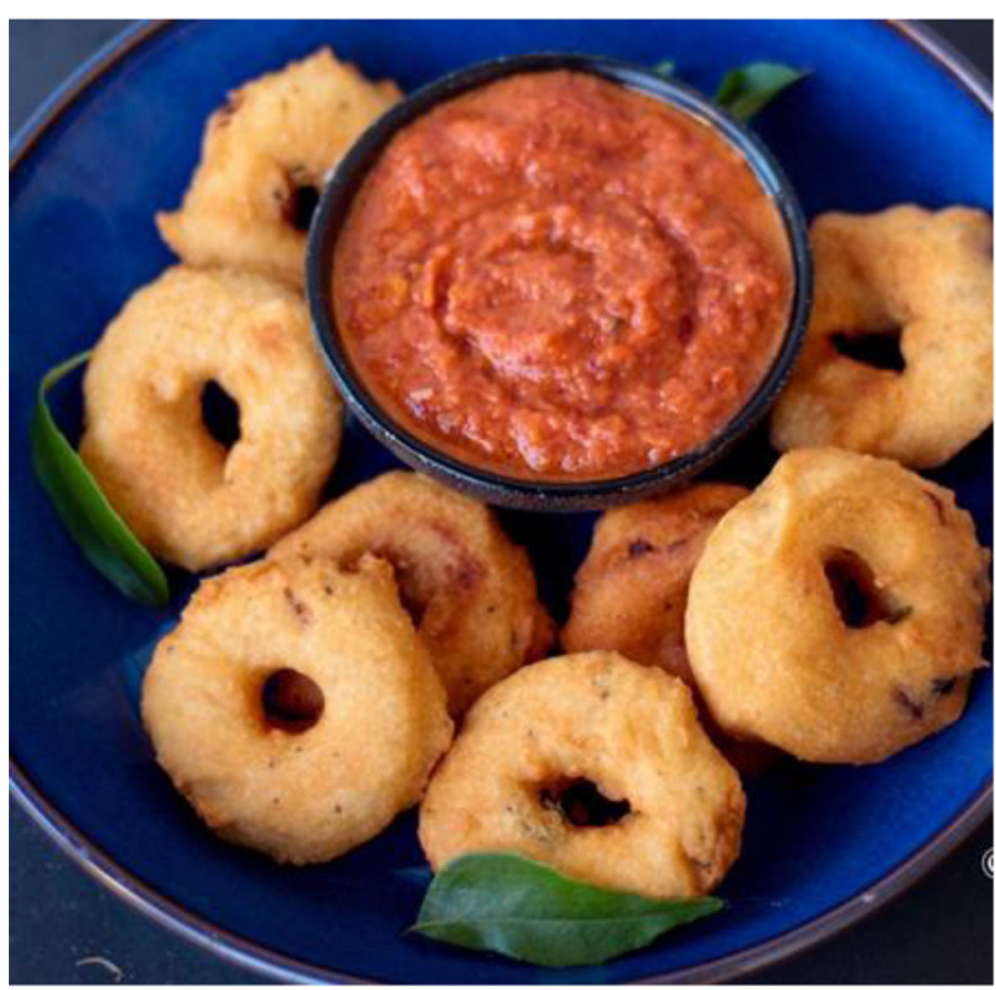

Fig. 2 Preparations advocated in Hemanta and Sisira Ritu: vada (recipe with black gram) 


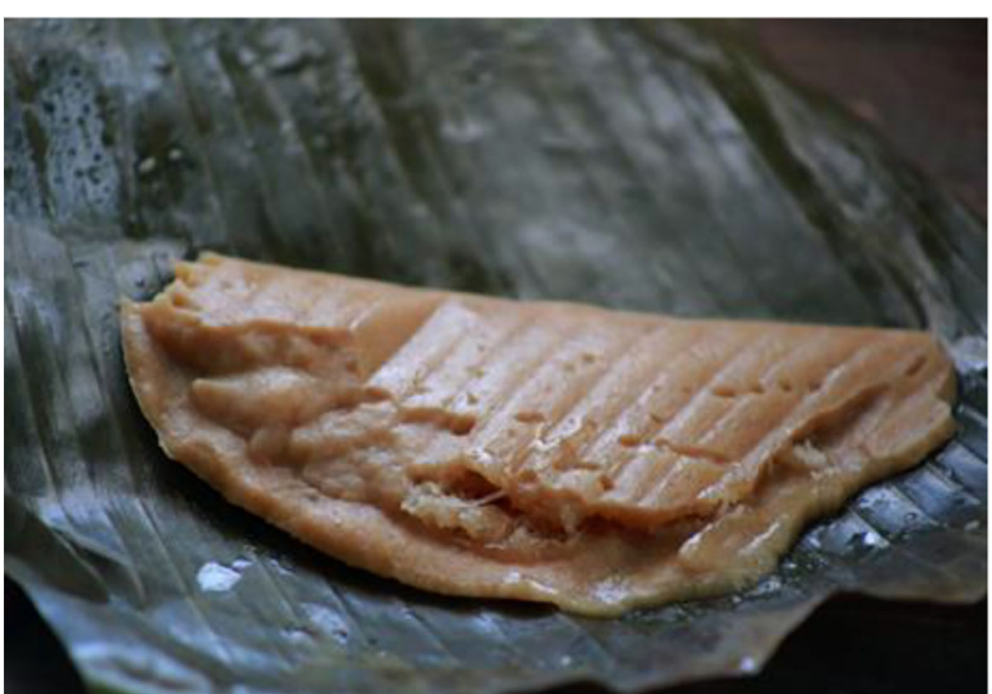

Fig. 3 Preparations advocated in Hemanta and Sisira Ritu: gothampu ela ada (recipe with wheat)

the high intake of dietary fibres consumed in this season as the species exhibit a negative correlation with it.

\section{Varsha Ritucharya (monsoon regimen)}

The Varsha Ritu (mid-July to mid-September) is characterised by a cold and humid climate with cloudy skies and occasional sun (Fig. 7). According to Ayurveda, the Amlata (acidity) of water, earth and environment increases causing pitta accumulation and vata vitiation in the human body. The body strength, immunity and digestive power tend to be less consequently. Hence, during this season, the use of ginger in diet, ginger with rock salt before a meal, whey or buttermilk with ginger, and foods/drink processed with honey is advocated [19]. Honey, composed primarily of fructose, glucose and fructo-oligosaccharides, has been considered as a favourable bifidobacterial substrate [20]. Shamala et al. [21] reports a population boom of lactic acid bacteria in the intestines of honey-fed rats, suggesting its capability to alter the intestinal microbiota.

An increase in the colon population of lactobacillus and bifidobacteria is therefore a harbinger of positive health multi-dimensionally by the production of SCFA, immune-stimulation, inhibiting the growth of

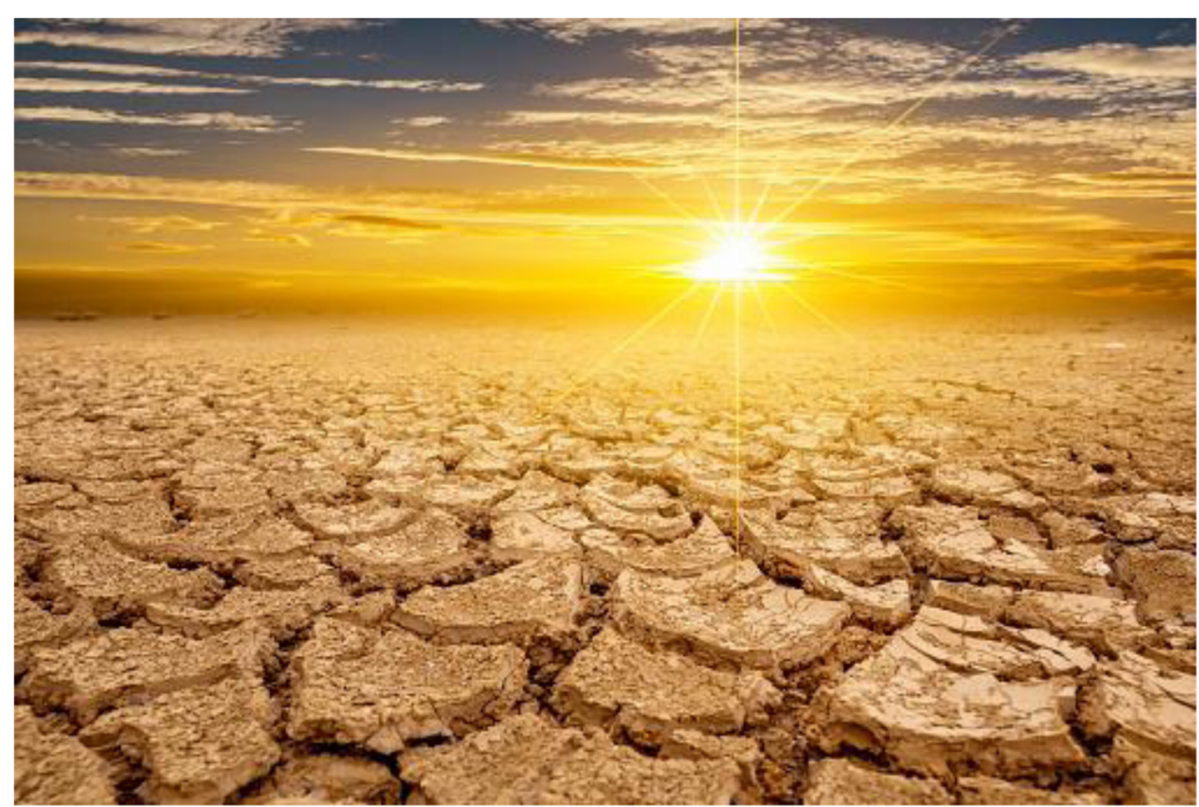

Fig. 4 Greeshma Ritu 

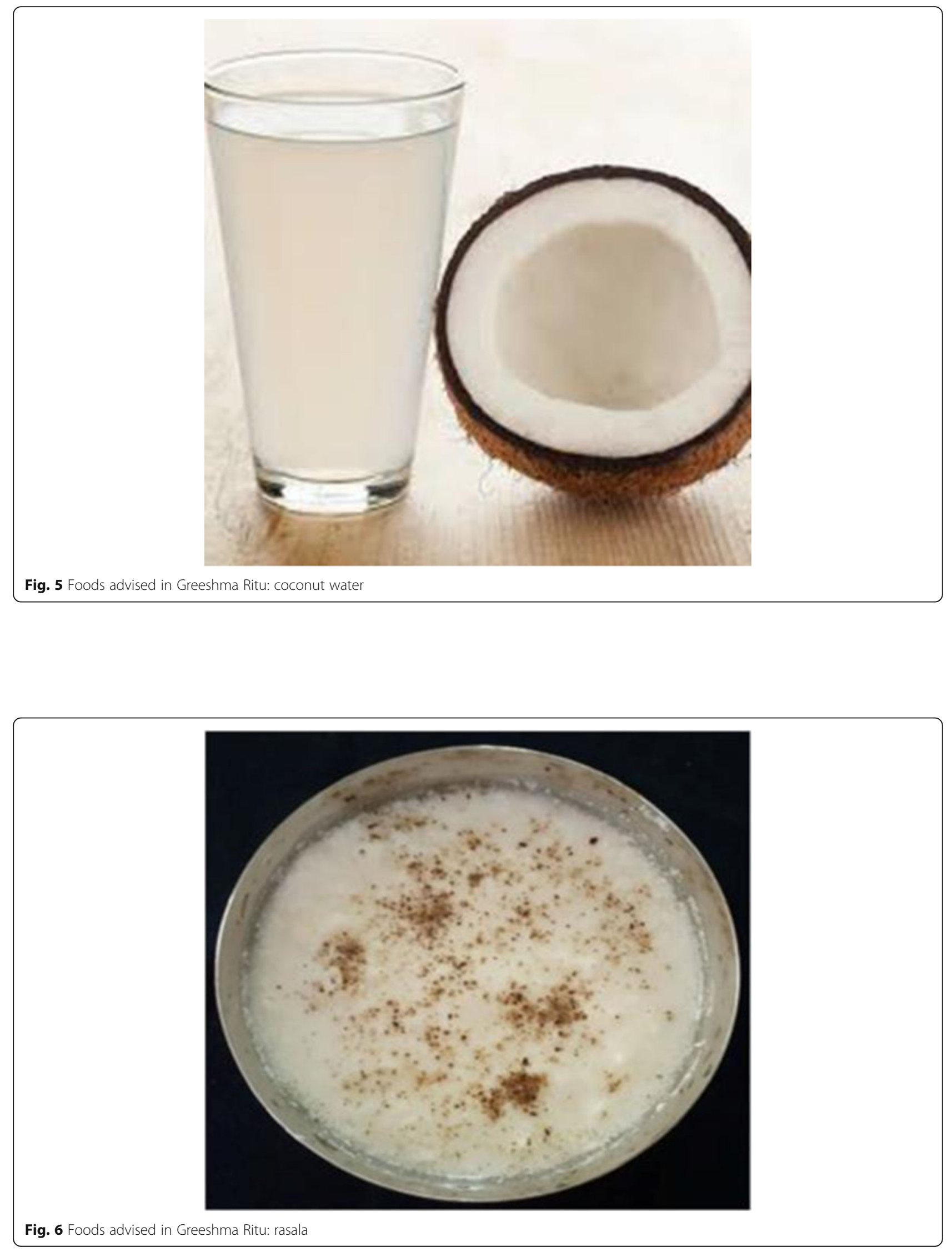


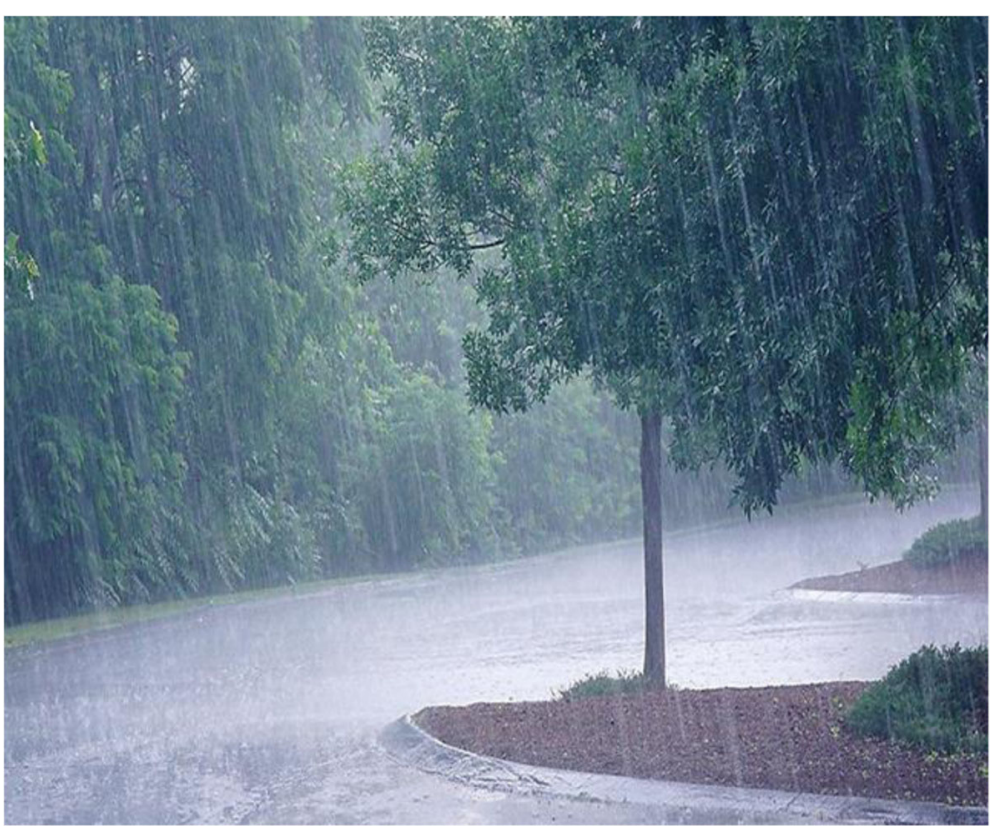

Fig. 7 The Varsha Ritu

pathogenic species and promoting the viability and nidation of live intestinal microbes, by fostering physical and metabolic activities of selected microbial species.

Various studies reveal that ginger favours the development of beneficial Bifidobacterium spp. and Bacteroides intestinalis whereas repress the opportunistic pathogen species like Escherichia coli, Klebsiella pneumonia and Bartonella quintana [22, 23]. Light and freshly prepared foods from old rice, barley, wheat and green gram are advised to be included in the daily menu during Varsha
Ritu. Fructo-oligosaccharides such as oligo-fructose and inulin, commonly found in garlic, onion, banana and wheat are also strongly bifidogenic [24] (Figs. 8 and 9).

\section{Conclusion}

This review examines the relevance of Ritucharya (seasonal regimen) based on the current evidence on the interdependency of gut microbial ecology with changing seasons and consequent health effects. The lifestyle and dietary factors can profoundly alter the commensal

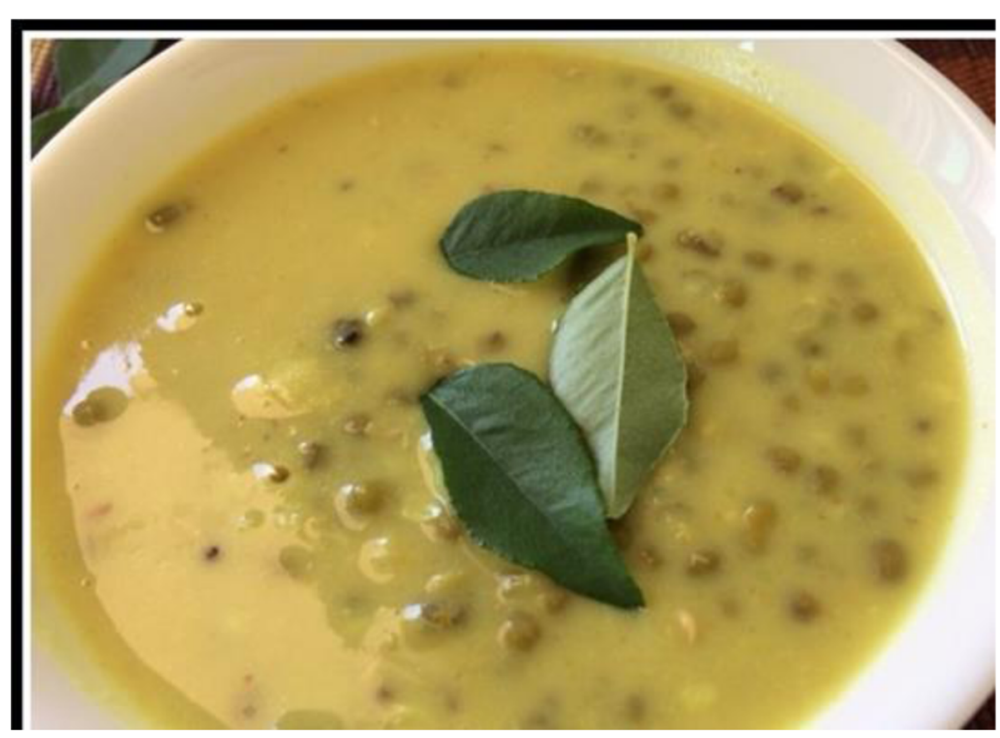

Fig. 8 Foods advised in Varsha Ritu: mudga yusha (green gram soup) 


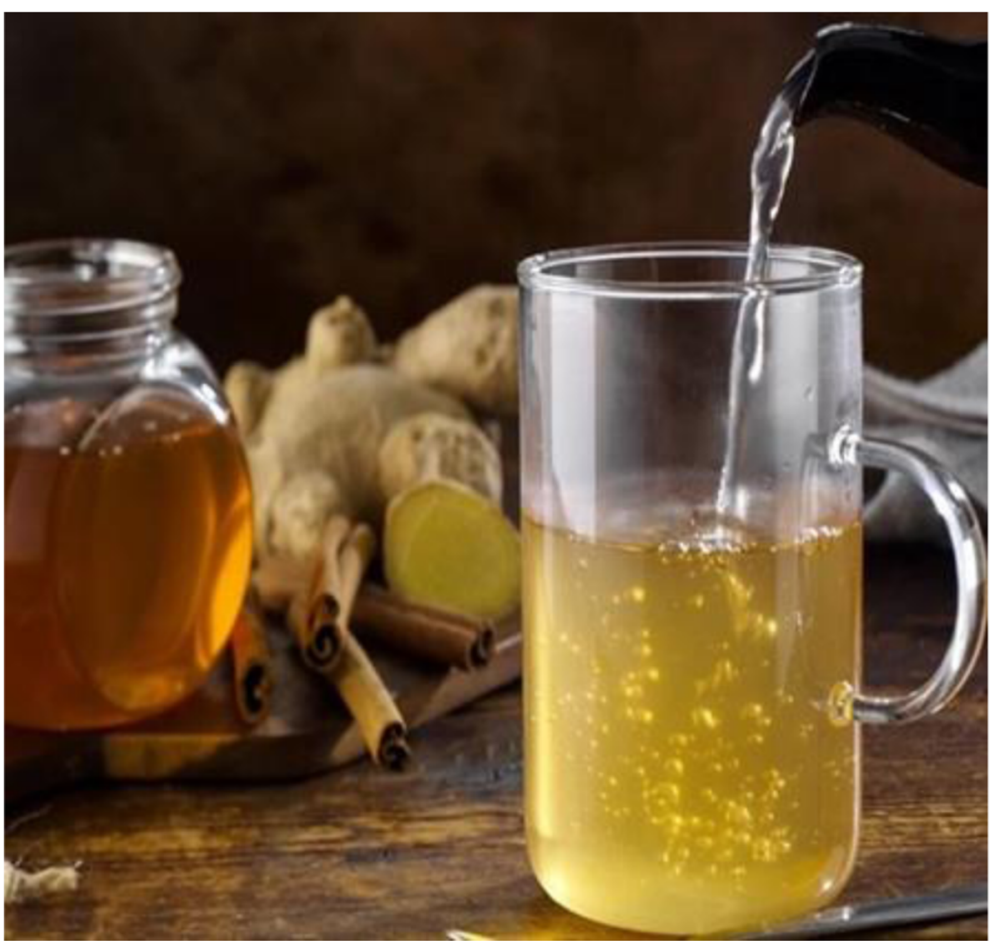

Fig. 9 Foods advised in Varsha Ritu: use of honey with water

microbial communities, the dysbiosis of which can augment pathogen susceptibility, inflammatory diseases and the current epidemic of metabolic health problems like non-communicable diseases. Adopting Ritucharya (seasonal regimen) could provide ample opportunity to attune the dynamics of human gut flora and rescue the host from the pathological manifestations of seasonal variations and other varied causes. Strict abidance to the seasonal regimens, resorting to seasonal foods etc., can alter the gut microbiome in sync to one that is conducive to health promotion. With a greater understanding of this gut microbiota-host relation, it is anticipated that we could harness our endogenous gut biome to prevent and treat a wide spectrum of diseases as well as to foster health.

\section{Abbreviations}

SCFAs: Short-chain fatty acids; IL-10: Interleukin 10; GABA: Gammaaminobutyric acid; CAZymes: Carbohydrate-active enzymes

\section{Acknowledgements}

We will be grateful for all the insightful comments towards the perfection of this work by the anonymous peer reviewers at the Journal of Ethnic Foods.

\section{Authors' contributions}

All authors contributed to the idea and overall construction of this manuscript. The authors reviewed and have approved the final manuscript and have agreed to the submission policies of the Journal of Ethnic Foods.

\section{Funding}

Not applicable.
Availability of data and materials

The data is obtained from major textbooks of Ayurveda, Charaka Samhita, Sushruta Samhita, and Ashtanga Samgraha and by reviewing original research and review articles from national and international journals, the details of which are attached in the reference section.

\section{Declarations}

\section{Competing interests}

The authors declare that they have no competing interests.

Received: 13 August 2020 Accepted: 3 May 2021

Published online: 13 May 2021

\section{References}

1. Arumugam M, Raes J, Pelletier E, Le Paslier D, Yamada T, Mende DR, et al. Enterotypes of the human gut microbiome. Nature. 2011;473(7346):174-80. https://doi.org/10.1038/nature09944.

2. Alan W, Walker JI, Duncan SH, Lucy M. Dominant and diet-responsive groups of bacteria within the human colonic microbiota. ISME J. 2011;5: 220-30.

3. Bailey MT, Walton JC, Dowd SE, Weil ZM, Nelson RJ. Photoperiod modulates gut bacteria composition in male Siberian hamsters (Phodopus sungorus). Brain Behav Immun. 2010;24(4):577-84. https://doi.org/10.1016/j.bbi.2009.12. 010.

4. Davenport ER, Mizrahi-Man O, Michelini K, Barreiro LB, Ober C, Gilad Y. Seasonal variation in human gut microbiome composition. Plos One. 2014; 9(3):e90731

5. Smits SA, Leach J, Sonnenburg ED, Gonzalez CG, Lichtman JS, Knight R, et al. Seasonal cycling in the gut microbiome of the Hadza hunter-gatherers of Tanzania. Science. 2017;357(6353):802-6. https://doi.org/10.1126/ science.aan4834.

6. Chevalier C, Stojanović O, Colin DJ, Suarez-Zamorano N, et al. Gut microbiota orchestrates energy homeostasis during cold. Cell. 2015;163(6): 1360-74. https://doi.org/10.1016/j.cell.2015.11.004.

7. K.R. Srikantha Murthy. Ashtanga Samgraha Of Vagbhatta, English translation vol.1, Chaukhambha Orientalia, Sutrasthana 4/14-16, p.61. 
8. Sharma C, Singh BP, Thakur N, Gulati S, et al. Antibacterial effects of Lactobacillus isolates of curd and human milk origin against food-borne and human pathogens. Biotech. 2017;7(1):31. https://doi.org/10.1007/s13205-0160591-7 PMCID: PMC5388649.

9. Campbell SC, Wisniewski PJ, Noji M, et al. The effect of diet and exercise on intestinal integrity and microbial diversity in mice. Plos One. 2016;11(3):1-17. https://doi.org/10.1371/journal.pone.0150502.e0150502.

10. Evans CC, LePard KJ, Kwak JW, Stancukas MC, Laskowski S, Dougherty J, et al. Exercise prevents weight gain and alters the gut microbiota in a mouse model of high fat diet-induced obesity. Plos One. 2014;9(3). https:// doi.org/10.1371/journal.pone.0092193.e92193.

11. Abulizi N, Quin C, Brown K, Chan YK, Gill SK, Gibson DL. Gut mucosal proteins and bacteriome are shaped by the saturation index of dietary lipids. Nutrients. 2019;11(2):1-24. https://doi.org/10.3390/nu11020418.

12. de Wit N, Derrien M, Bosch-Vermeulen H, Oosterink E, Keshtkar S, Duval C, et al. Saturated fat stimulates obesity and hepatic steatosis and affects gut microbiota composition by an enhanced overflow of dietary fat to the distal intestine. Am J Physiol Liver Physiol. 2012;303(5):G589-99. https://doi. org/10.1152/ajpgi.00488.2011.

13. Wu GD, Chen J, Hoffmann C, Bittinger K, Chen YY, Keilbaugh SA, et al. Linking long-term dietary patterns with gut microbial enterotypes. Science. 2011;334(6052):105-8. https://doi.org/10.1126/science.1208344.

14. Li B, Li L, Li M, Jin W, Shui G, Speakman JR. Microbiota depletion impairs thermogenesis of brown adipose tissue and browning of white adipose tissue. Cell Rep. 2019. https://doi.org/10.1016/j.celrep.2019.02.015.

15. Goodrich JK, Waters JL, Poole AC, Sutter JL, et al. Human genetics shape the gut microbiome. 2014;Cell, 159(4):789-99. https://doi.org/10.1016/j.cell.2014. 09.053 PMCID: PMC4255478.

16. K.R. Srikantha Murthy. Ashtanga Samgraha Of Vagbhatta, English translation vol.1, Chaukhambha Orientalia, Sutrasthana 4/33-35, 64.

17. Kolida S, Tuohy K, Gibson GR. Prebiotic effects of inulin and oligofructose. Br J Nutr. 200287 Suppl 2:S193-S197 Food Microbial Sciences Unit, School of Food Biosciences, The University of Reading, Whiteknights

18. Mahowald MA, Rey FE, Seedorf H, Turnbaugh PJ, Fulton RS, Wollam A, et al. Characterizing a model human gut microbiota composed of members of its two dominant bacterial phyla. Proc Natl Acad Sci USA. 2009;14:5859-64. https://doi.org/10.1073/pnas.090152910619.

19. K.R. Srikantha Murthy. Ashtanga Samgraha Of Vagbhatta, English translation Vol.1, Chaukhambha Orientalia, Sutrasthana 4/44,46, p.65.

20. Kajiwara S, Gandhi H, Ustunol Z. Effect of honey on the growth of and acid production by human intestinal Bifidobacterium spp.: an in vitro comparison with commercial oligosaccharide and inulin. J Food Prod. 2002; 65(1):214-8. https://doi.org/10.4315/0362-028X-65.1.214.

21. Shamala TR, Shri Jyothi Y, Saibaba P. Stimulatory effect of honey on multiplication of lactic acid bacteria under in vitro and in vivo conditions. Lett Appl Microbiol. 2000;30:453-5.

22. Sharifi-Rad M, Varoni EM, Salehi B, et al. Plants of the genus Zingiber as a source of bioactive phytochemicals: from tradition to pharmacy. Molecules. 2017;22:12.

23. Lu QY, Summanen PH, Lee RP, Huang J, Henning SM, Heber D, et al. Prebiotic potential and chemical composition of seven culinary spice extracts. J Food Sci. 2017;82(8):1807-13. https://doi.org/10.1111/1750-3 841.13792.

24. Bouhnik Y, Vahedi K, Achour L, Attar A, Salfati J, Pochart P, et al. Shortchain fructo-oligosaccharide administration dose dependently increases fecal bifidobacteria in healthy humans. J Nutr. 1999;129(1):113-6. https://doi.org/1 0.1093/jn/129.1.113.

\section{Publisher's Note}

Springer Nature remains neutral with regard to jurisdictional claims in published maps and institutional affiliations.

Ready to submit your research? Choose BMC and benefit from:

- fast, convenient online submission

- thorough peer review by experienced researchers in your field

- rapid publication on acceptance

- support for research data, including large and complex data types

- gold Open Access which fosters wider collaboration and increased citations

- maximum visibility for your research: over $100 \mathrm{M}$ website views per year

At BMC, research is always in progress.

Learn more biomedcentral.com/submissions 